\title{
Development of Real Estate Investment Trust (REIT) Regimes in Europe
}

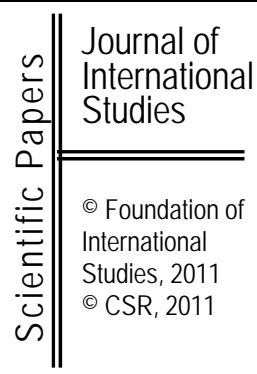

PhD Anna Mazurczak

Department of Real Estate and Investment

Poznan University of Economics

anna.zaja@@ue.poznan.pl

\begin{abstract}
The purpose of this paper is to examine the existing REIT (Real Estate Investment Trust ${ }^{1}$ ) regimes in Europe and to analyse whether REITs can be successful investment vehicle on the European markets. REIT is an investment regime that provides an efficient solution for small investors to participate in commercial real estate markets, avoiding real estate disadvantages as part of an investment portfolio. It is possible that the REIT concept will developed in all EU member states introducing real estate companies and their investors with new opportunities. In this paper main features and challenges of REIT regimes will be discussed.
\end{abstract}

Keywords: real estate, investment fund, Real Estate Investment Trust (REIT), investment, real estate fund.

JEL classification: L85, G24.

\section{Introduction}

During the first half of 2011 Real Estate Investment Trusts (REITs), after two years of the financial crisis, have showed an impressive growth. All REIT regimes around the world respond to the changing market environment and are continuously evolving. The future development of REIT regimes is expected to significantly increase the number of listed real estate companies in Europe. Simultaneously, it will increase alternative real estate investment opportunities for individual and institutional investors.

Real estate is an important part of investment portfolio of many institutional as well as individual investors. Unfortunately, because of some special features of real estate assets like lack of liquidity, lack of efficiency, lack of relevant performance measurement as well as high capitalization, private investors are limited in real estate direct investment. For most of the private investors the above mentioned barriers preventing them from participation in the ownership of large commercial real estate. The solution is to create alternative forms of indirect real estate investments, among which real estate investment funds or trust play crucial role.

To facilitate private and institutional investors, numerous countries have created special tax regimes for property companies - REITs, so as to avoid double taxation, and to

\footnotetext{
${ }^{1}$ Real Estate Investment Trust (REITs) - a tax conduit company dedicated to owning, managing and operating income-producing real estate.
} 
create a level playing field between different forms of real estate ownership. The goal of these regimes is to avoid taxing a rental income stream at the corporate level and again at the shareholder level. Thus, exemption from corporate tax for a property company puts the shareholder in such a property company in a comparable position with an investor who owns a property portfolio outright, since the rental stream for such an investor will only be taxed as income. In other words, corporate tax exemption creates a level playing field between the direct segment and the indirect segment of the property market. In this sense, such tax treatment of property companies is analogous to the corporate tax-exemption of mutual funds, for which a corporate tax levy would also entail double taxation (Eichholtz, Kok, 2007, p. 2). Moreover, REITs enable especially private investors to participate in the commercial real estate investments.

On the one hand, REITs are important from the investor's point of view. On the other hand, this regime is also crucial for real estate financing system, collecting capitals from as many investors as possible. Therefore, REITs are investment vehicle that are prefect for different types of investors, as well as source of capitals needed for real estate markets development.

The main goal of the study is to introduce REITs structures around the world, especially in EU countries, and analyse its development process. Moreover, the author of this paper, will try to explain the importance of REITs introduction on different markets. These days, when we discuss globalisation aspects of capitals financing real estate markets, the idea of REITs may by the answer how to benefit from that. Creating one similar, however, not exactly the same for all countries, EU REIT, would turn the current fragmented EU market for property companies into the largest and likely most efficient property share market in the world. Investors, small and large, private and institutional, would greatly benefit from that.

\section{History and performance of REIT}

The establishment of tax-efficient, REIT-type regimes in Europe is not the new idea. The Netherlands introduced its system in 1969, and other countries in Central and Southern Europe have been early adopters. In 2011 there were 13 European countries that introduced REIT regimes.

The first REITs structure was officially introduced in 1960 by the US Congress. The 1960 law originally defined REITs as an unincorporated association with multiple trustees as managers and having transferable shares of beneficial interest (Han Chan, Ericsson, Wang, 2003, p.15). It allowed individual real estate investors to take advantages of the same benefits as direct real estate owners. This federal law allowed REITs to avoid taxation at the corporate level on income distributed to shareholders and created the basis for present REITs structure.

Boom in REITs investment appeared throughout the 1980s when the Tax Reform Act of 1986 eliminated many real estate tax shelters. The Tax Reform Act of 1986 enabled REITs to manage their properties directly, and in 1993 REIT investment barriers to pension funds were eliminated (Imperiale, 2006, p. 4). This path of reforms continued to increase the opportunity for REITs to make high-quality property investments. Nowadays US REITs own approximately $\$ 500$ billion of commercial real estate assets, or $10-15 \%$ of total institutionally owned commercial real estate. 
Table 1. US REITs characteristics

\begin{tabular}{|l|l|}
\hline Total equity market capitalization & \$248 billion \\
\hline Equity REIT market capitalization & \$222 billion \\
\hline $\begin{array}{l}\text { The number of REITs that are in the Financial Times Stock Exchange } \\
\text { (FTSE) NAREIT }{ }^{2} \text { All REIT Index }\end{array}$ & 142 REITs \\
\hline $\begin{array}{l}\text { The Number of REITs that are traded on the New York Stock Exchange } \\
\text { (NYSE) }\end{array}$ & 127 REITs \\
\hline NYSE listed REITs equity market capitalization & \$245 billion \\
\hline
\end{tabular}

Source: NAREIT, REIT Watch, October 2009.

The Australian REITs market has a history dating back to 1971, when the first REIT was listed on the Australian Stock Exchange (ASX). The Australian REITs market is now very large, well established and sophisticated with approximately $70 \%$ of Australian investment grade properties securitized. As of 28 February 2011, there were 57 listed REITs on the ASX with a market capitalization of over $\$ 80$ billion.

In Europe, REITs were first introduced in Netherlands and France, followed by the UK and Germany in 2007. According to European Public Real Estate Association (EPRA), Europe accounts for just $21,8 \%$ of the global REITs market capitalization estimated at $€ 754$ billion, despite having $42,3 \%$ of the world's underlying assets in the direct commercial property market. The small size of European listed real estate assets compared to total property stocks $(4,9 \%)$ suggests great potential for growth.

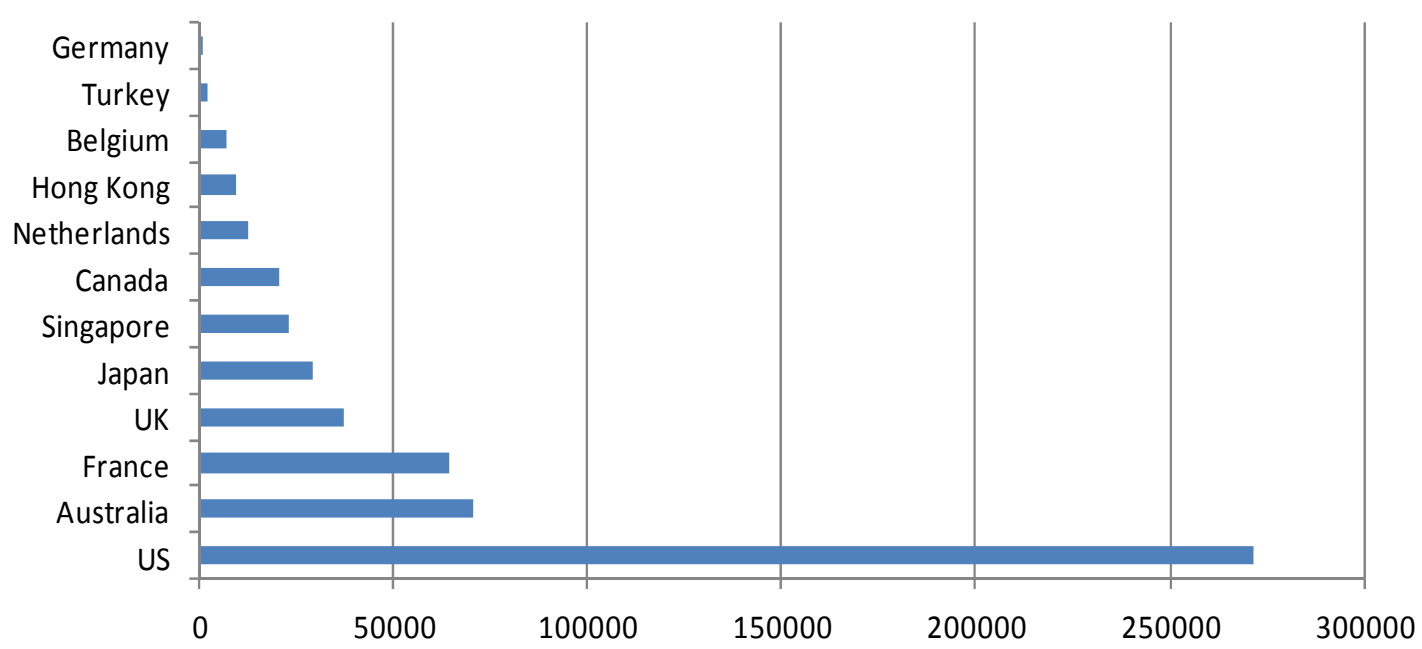

Graph 1. Market capitalization - total (USD millions)

Source: Global Real Estate Investment Trust Report 2010, Against all odds, Ernst\&Young.

\footnotetext{
${ }^{2}$ The National Association of Real Estate Investment Trusts (NAREIT) is the worldwide representative voice for REITs and publicly traded real estate companies with an interest in U.S. real estate and capital markets. NAREIT's members are REITs and other businesses throughout the world that own, operate, and finance income-producing real estate, as well as those firms and individuals who advise, study, and service those businesses.
} 


\section{REITs definition, structure and types}

REIT is a company that owns, and in most cases, operates income-producing real estate, as apartments, office buildings, warehouses, shopping centres. Some REITs also engage in financing real estate. The shares of many REITs are traded on major stock exchanges. There are four aspects that must be fulfilled by the business trust or corporation to be considered a US - REIT for federal income tax purposes:

1. Organizational structure - the REIT must be organized as a business trust or corporation.

2. Nature of assets - at least $75 \%$ of the value of a REIT's total assets must be represented by real estate assets, cash and government securities; REIT may not own non-government securities in an amount greater than $25 \%$ of the value of the assets.

3. Sources of income - at least $75 \%$ of the company's income is derived from real estate or real estate - related investments. At least $75 \%$ of a REIT's annual gross income must consist of real estate rents, mortgage interest, gain from the sale of real estate assets, and other real estate - related sources (75\% test). At least $95 \%$ of a REIT's annual gross income must be derived from the income items from the preceding $75 \%$ test plus other passive income sources such as dividends and any type of interest.

4. Distribution of income $-90 \%$ of net income must be distributed to shareholders. If it is fulfilled, REIT may deduct all dividends paid to its shareholders and avoid federal taxation at the corporate level on the amount distributed (Imperiale, 2006, p.16).

There are approximately 170 publicly traded REITs in the US today, with a combined equity market capitalization of about \$ 135 billion. The shares of these companies are traded on major stock exchanges, which sets them apart from traditional real estate. Other REITs may be either publicly registered (but non-exchange traded) or private companies.

In the US REITs are classified in the following categories:

1. equity REITs which own and operate income-producing real estate, from apartments buildings to self-storage centres;

2. mortgage REITs which lend money directly to real estate owners and their operators, or indirectly through acquisition of loans or mortgage-backed securities;

3. hybrid REITs which are companies that both own properties and make loans to owners and operators.

In the 1970s, according to NAREIT, mortgage REITs were by far the life of the REITs party, holding about a three-to-one edge in investor allocations over equity REITs. In 1970, the count was almost $80 \%$ in mortgage REITs and $20 \%$ in equity REITs. But over the next 30 years those ratios changed, especially as the US went through several sustained commercial and residential housing booms. By the mid 1980s, it was more of a 50-50 comparison, and through most of the 1990s and the current decade the three-to-one ratio was essentially reversed in favour of equity REITs (Gordon, 2008, p. 28).

Special tax regimes and REITs structures depends on its country of origin. However, REITs have some advantages, that make it unique compared to other indirect real estate investment. These special characteristics are: geographical and functional diversification of real estate portfolios that allows individual investors to benefit from international property markets; low transaction costs; low entry costs and stable income from dividends; tax exemptions; high investment liquidity; high diversification of investment portfolio which viewed REITs as stable and safe investment. 


\section{EU markets for REIT}

REITs constantly increase their global presence, mainly through the adoption of its US concept with some minor adjustments. The reason why US structure is the base for other countries is its long and successful history. The potential benefits associated with the securitization of real estates, such as the increased liquidity and more efficient allocation or real estate capital, appeal property investors all over the world. How rapidly the foreign adaptation of the US REITs concept will occur will depend on a number factors, primarily the extent to which public policymakers in these countries view the REIT concept as a way to reinvigorate their real estate markets (Han Chan, Erickson, Wang, 2003, p. 256).

While REITs have years of history in Australia and the US, they constitute a fairly new asset class in Europe. There is no EU internal market for REITs, and the EU member states cannot take advantages of the common REITs structure. According to this private individuals, as well as institutional investors don't have wide spectrum of possibilities existing in US and other global markets. So far, numerous countries, for example Germany or United Kingdom, have created tax basis for REIT enable to avoid double taxation, and to create a level playing field between different forms of real estate ownership. The main goal of this is to avoid taxing a rental income stream at the corporate level and again at the shareholder level. As a result, corporate tax exemption creates a level playing field between the direct and indirect property market investment. Legislation regarding tax exemption of real estate companies has been introduced in 12 out of the $27 \mathrm{EU}$ countries so far.

There are some discussions in field of REITs future in Europe. According to the Maastricht University report "The EU REIT and the Internal Market for Real Estate" (November 2007) investors have long been conscious of the problems raised by the lack of an EU REIT structure, but for the first time sheds light on the scale of the challenge:

- the need to address increasing distortions of competition as national REITs multiply,

- the opportunity to buttress market safety and security. Simply by ensuring a properly functioning Internal Market for real estate investment, the EU can make a major contribution to the control and stabilization of property markets the need to correct a situation where investors in small member states cannot access good quality property investment in other member states or even the prime property investments in their own countries,

- the opportunity to reverse the current trend of initiators of property companies to resort to tax havens the chance to boost specialization in cutting edge real estate and investment in social property that both require development on a European scale (Eichholtz, Kok, 2007).

The report goes further, outlining a preferred structure for an EU REIT with no need for invasive tax harmonization as no approximation of tax rates on shareholder dividends is required. The report also provides the key characteristics of a blueprint for EU REIT regime. The key characteristics are as follows:

- the EU REIT regime should leave maximum freedom for the management of property companies to engage in value creation for their shareholders.

- property development by EU REITs should be allowed, but taxed in such a way that a level playing field with pure property developers is maintained.

- the EU REIT should have a closed-end structure and could have internal management (Eichholtz, Kok, 2007).

The most important question is whether it is possible to create one unique structure for all EU member states. The idea of REITs is not to be the same on all markets, but to be based on the similar frames. The process of implementing REITs regimes is in progress. There are differences among different markets, however, the idea stays the same. 


\section{REIT structures introduced in EU member states}

The property market regimes in the EU are characterized by variety and fragmentation. Most of the 27 EU member states have its own funds structures and its own legislation. This fragmented market situation in the EU contrasts with the situation in the US or Asian markets, which has one and the same property share regime in every single state, enabling the development of a property share market that is now bigger than all of the EU's national property share markets combined. The market size created by this one legal regime enables property companies in the US to harvest economies of scale and scope that are out of reach for their European counterparts. On the other hand, it is hard to compare US states with EU members.

According to the EPRA Global REIT Survey 2009, the existing unified regimes of EU-REITs are presented below.

Table 2. REIT structures in EU member states

\begin{tabular}{|c|c|c|c|}
\hline Country & Structure name & Year & $\begin{array}{l}\text { \%of global } \\
\text { REIT market }\end{array}$ \\
\hline Belgium & Sicafi/Bevak & 1995 & 1,4 \\
\hline Bulgaria & REIT & 2004 & 0,1 \\
\hline Finland & FINNISH REIT & 2009 & 0 \\
\hline France & SIIC & 2003 & 11,3 \\
\hline Germany & G-REIT & 2007 & 0,1 \\
\hline Greece & REIC & 1999 & 0,2 \\
\hline Italy & FII & 2007 & 0,1 \\
\hline Lithuania & & 2008 & 0 \\
\hline Luxembourg & SICAV & 2007 & 0 \\
\hline Netherlands & FBI & 1969 & 2,1 \\
\hline Spain & SOCIMI & 2009 & 0 \\
\hline UK & UK-REIT & 2007 & 6,5 \\
\hline
\end{tabular}

Sources: EPRA Global REIT Survey (Sept. 2009).

The Belgian equivalent to the REITs regime is known as the SICAFI (Société d'Investissement en Immobilier à Capital Fxe), and forms part of the Belgian legal system. The SICAFI was enacted in 1995 based on the Act of December 04, 1990, which was partially abrogated and replaced by the Law of July 20, 2004 on certain forms of management of collective investment undertakings, and the Royal Decree of April 10, 1995. The law of June 16, 2006, which implemented the Prospectus Directive, modified the prospectus requirements of the Law of July 20, 2004. The SICAFI is also subject to specific tax rules. There are 14 companies registered as REIT with market capitalization of $€ 4$ billions.

In Bulgaria the REIT regime was introduced with the Special Investment Purpose Companies Act (SPIC), which came into force on January 01, 2004. There are 19 REITs with $€ 0.2$ billion of market capitalization.

The Finnish REIT was introduced with effect from January 01, 2009 by the Finnish Act on Tax Incentives for certain Limited Companies Carrying on Residential Renting Activities (24.4.2009/299). Under this regime, a Finnish REIT is fully exempt from paying corporate income tax. However, penalty tax charges may apply on a REIT in certain circumstances. No REITs have yet been created under the regime yet. 
France is the biggest REITs market in Europe. Article 11 of the Finance Act for 2003 introduced a pure tax regime applicable to listed real estate asset investment companies. The SIIC regime has been amended by the Amended Finance Act for 2004, the Finance Act for 2005, the Amended Finance Act for 2006, the Amended Finance Act for 2007, the Finance Act for 2008 and the Finance Act for 2009. In addition, the French Tax Authorities (FTA) published administrative tax guidelines on September 25, 2003. Until June 2009 there have been 46 REITs created in France with $€ 32,2$ billions of market capitalization.

After intensive three-year political discussions, Germany implemented the German Real Estate Investment Trust (G-REIT) in 2007 in order to meet the market demands inspired by the introduction of the REIT in other European countries. The G-REIT is a joint stock company with specific rules laid out by the REITs law. The REITs law came into force on June 01, 2007 with retroactive effect as of January 01, 2007. The REITs law is supported by changes in various tax laws, such as the German Income Tax Act and the Investment Tax Act. The REITs law has been amended by the Tax Amendment Act 2009 (Jahressteuergesetz, 2009). One of the major changes was that shareholders may benefit from the privileged taxation generally applicable for dividend income if such dividends are sourced by pre-taxed profits of the G-REIT and certain further requirements are fulfilled.

The tax authorities published on July 10, 2007 an administrative guidance according to which upon registration as a REIT with the Commercial Register, tax exemption is to be assumed to start with the beginning of the year of registration, and therefore upon application, no tax prepayments are to be assessed. Up to now two REITs are listed, and 12 companies are registered at the Federal Central Tax Office (Bundeszentralamt für Steuern) as pre-REITs. The listed companies, Alstria AG and Fair Value AG, have together a market capitalization of approximately EUR 0.4 billion.

Greek Law recognizes the legal forms of Real Estate Mutual Funds (REMF) and Real Estate Investment Companies (REIC) which are basically regulated by Law 2778/1999 (hereafter 'REIT law'). Although the exact term 'REIT' does not exist in the Greek legislation, the REIC could be qualified as such. The REIT law was introduced in December 1999, and has been amended thereafter by L. 2992/ 2002. Only two REICs currently exist in Greece and they have been set up and managed by Greek banks. The investor base of those REICs is predominantly made up of Greece-resident companies and individuals. The tax and regulatory legislation applicable to Greek REICs is often imprecise and several grey areas still exist, particularly in respect of certain tax aspects of REICs.

In December 2006, a new real estate investment regime was implemented in the Italian legislation. The regime, applicable to the Società d'Intermediazione Immobiliari Quotate (SIIQ), is effective as of July 01, 2007. The introduction of this regime was aimed to attract investments in the Italian real estate market. Consequently, the new REIT regime is supplementary to the pre-existing real estate investment fund regime (REIF). The REIT allows investors to have greater influence in the effective management of the companies, especially in terms of investments and governance. According to the pre-existing REIF, investors were excluded from the decision making that concerned the investment fund. The new SIIQ regime was introduced by the 2007 Italian Budget Law. However, the regulatory provisions were implemented on October 2007 by means of a Ministerial Decree. In addition, in November 2007, the Revenue's Office issued a measure that effectively introduced the possibility to opt for the application of the SIIQ tax regime.

On the November 11, 2007 the Lithuanian Parliament amended the Law on Collective Investment Undertakings, which came into force on the March 01, 2008. The law regulates management activities of collective investment undertakings and therefore the activities of REITs. Since the Law on Collective Investment Undertakings does not provide for a new 
form of entity, REIT is incorporated as a joint stock company under the Lithuanian company law or an investment fund, managed by a management company.

Although, Luxembourg has not enacted a REITs regime, the Specialized Investment Fund (SIF) regime enacted on the February 13, 2007 has developed into a specialized property fund regime in a little over a year. It is not outwardly labelled as a REITs regime, however, parliamentary history confirms its real estate fund purpose. A SIF should be any undertaking for collective investment situated in Luxembourg the exclusive object of which is the collective investment of its funds in assets in order to spread the investment risks and to ensure for the investors the benefit of the results of the management of its assets, and the securities of which are reserved to one or several well-informed investors, and the constitutive documents or offering documents of which provide that it is subject to the provisions of the law of February 13, 2007, relating to specialized investment funds (the SIF Law). The SIF Law replaces the law of July 19, 1991 relating to undertakings for collective investment, the securities of which are not intended to be placed with the public.

The Netherlands introduced the Fiscal Investment Institution regime (Fiscale Beleggingsinstelling: FBI) in 1969. The FBI does not benefit from an exemption from corporate income tax as such. Instead, it is subject to a corporate income tax rate of $0 \%$ (full exemption). The FBI regime has been incorporated in the Dutch Corporate Income Tax Act 1969 (Wet op de vennootschapsbelasting 1969: CITA) and should be considered a tax facility. It may also apply to other passive, portfolio investments than real estate. In 2007, the FBI regime was amended to comply with EU law regulations. It has become possible for a foreign entity to apply for the regime. Further, certain restrictions which prohibited foreign shareholders to invest in an FBI have been abolished.

The Bill governing the 'Sociedades Anónimas Cotizadas de Inversión en el Mercado Inmobiliario' (the so-called 'SOCIMI') introduces to the Spanish real estate market a longawaited REIT vehicle. However, SOCIMIs, unlike other European REITs will be taxed at a fat $18 \%$ tax-rate. This tax will be the final tax for Spanish Personal Income Tax taxpayers and for Non-Resident (without permanent establishment in Spain) taxpayers, as generally none of them will be taxed on dividends and capital gains derived from their investment in a SOCIMI. The Bill is expected to be enacted during the last quarter of 2009.

The UK-REIT was introduced in the UK with effect from 1 January 01, 2007 by the Finance Act 2006. On 1 January 01, 2007 nine companies elected to become REITs - a number which grew significantly within the first year of the regime, but which has stabilized since. The UK REIT regime operates through a combination of legislation (primary and secondary) plus guidance. The primary legislation is currently being rewritten as part of an ongoing process to simplify the UK's tax legislation. The rewritten legislation will form part of the Corporation Tax Act 2010. There will also be updated guidance to accompany the legislation. The UK REIT market currently consists of 21 REITs, 19 of which are FTSE listed.

\section{Conclusions}

The analyse of existing REITs structures in Europe showed that European REITs market is fragmented. Moreover, most of the EU member states mainly adopt its real estate investment funds legislation to create REITs structure. The effect is obvious and only existing companies convert into REITs, but there are no newcomers (like in UK). There are also exceptions, like France, where REITs market is developing and its portfolios are growing. Those differences in effects of implementing REITs are basically resultant of size of the market, competition of alternative investment vehicles, especially real estate funds, and also macroeconomic situation an level od real estate market development. In countries like Poland, 
where there is bigger need for capital financing real estate market, haven't implemented REITs structures yet.

It is possible that the REIT concept will developed in all EU member states introducing real estate companies and their investors with new opportunities. The future success of REIT will depend mainly on how effective REITs managers are in adopting changes in the capital markets and finding new ways to improve profitability from their direct and non-direct investment. Moreover, we cannot forget about the crucial role of local governments and authorities in creating special tax structure for effective REITs development. On the other hand, it is doubtful that there will be one unique for all member states EU-REIT regime.

\section{References}

Block, R. (2002), Investing in REITs, Bloomberg Press, Princeton, NJ, USA.

Eichholtz, P., Kok, N. (2007), The EU REIT and the Internal Market for Real Estate. A research report for the European Landowners' Organization, the European Property Federation, the Royal Institution of Chartered Surveyors, The European Group of Valuers' Associations, and the Urban Land Institute Europe, Maastricht University.

Garrigan, R., Parsons, J. (1997), Real Estate Investment Trusts. Structure, Analysis and Strategy, The McGraw-Hill companies, Inc., New York, US.

Gordon, M. (2008), The complete guide to investing in Real Estate Investment Trusts, Atlantic Publishing Group, Inc.

Imperiale, R. (2006), Getting started In Real Estate Investment Trusts, John Wiley\&Sons, Inc., Hoboken, New Jersey, USA.

Su Han Chan, Ericsson, J., Wang, K. (2009), Real Estate Investment Trusts. Structure, Performance, and Investment Opportunities, Oxford University Press, Oxford, UK.

EPRA Global REIT Survey, September 2009.

Compare and contrast: Worldwide Real Estate Investment Trust (REIT) Regimes, PriceWaterhouseCoopers Report 2010. 